\title{
Short- and longer-term effects of feeding increased metabolizable protein with or without an altered amino acid profile to dairy cows immediately postpartum
}

\author{
E. G. Carder and W. P. Weiss ${ }^{1}$ \\ Department of Animal Science, Ohio Agricultural Research and Development Center, The Ohio State University, Wooster 44691
}

\begin{abstract}
The first few weeks after parturition is marked by low, but increasing feed intake and sharply increasing milk production by dairy cows. Because of low intake, the nutrient density of the diet may need to be higher during this period to support increasing milk yields. We hypothesized that feeding higher levels of metabolizable protein (MP) or a protein supplement with rumen-protected lysine and methionine during the immediate postpartum period would increase yields of milk and milk components. Fifty-six Holstein cows (21 primiparous and 35 multiparous) starting at $3 \mathrm{~d}$ in milk were used in a randomized block design. In phase 1 ( 3 through $23 \mathrm{~d}$ in milk), cows were fed 1 of 3 diets that differed in supply of MP and AA profile. At 23 $\mathrm{d}$ in milk, all cows were moved to a common freestall pen and fed the control diet used in phase 1 for an additional $63 \mathrm{~d}$ (phase 2). Diets were formulated using the National Research Council model and were control $[16.5 \%$ crude protein (CP), $10.9 \%$ rumen-degradable protein (RDP), and $5.6 \%$ rumen-undegradable protein (RUP)], high MP (HMP; 18.5\% CP, $11.6 \%$ RDP, $6.9 \%$ RUP), and AA (MPAA; $17.5 \%$ CP, $10.5 \%$ RDP, $7.0 \%$ RUP 29.7). The MPAA diet included a proprietary spray-dried blood meal product (Perdue Agribusiness, Salisbury, MD) and contained a model-estimated 7.2 and $2.6 \%$ of digestible lysine and methionine (\% of MP). The HMP and control diets contained 6.3 and $6.7 \%$ digestible lysine and both had $1.8 \%$ digestible methionine. In phase 1 , diet did not affect milk yield $(33.6,34.7$, and $33.2 \mathrm{~kg}$ for control, HMP, and MPAA, respectively), dry matter intake $(17.8,18.0$, and 18.5 $\mathrm{kg} / \mathrm{d}$ for control, HMP, and MPAA), or milk protein yield $(1.07 \mathrm{~kg} / \mathrm{d})$. Feeding additional protein (HMP or MPAA) increased both the concentration and yield of milk fat, and milk protein concentration was greater (3.30 vs. 3.17\%) for MPAA compared with the HMP
\end{abstract}

Received November 27, 2016.

Accepted February 26, 2017.

${ }^{1}$ Corresponding author: weiss.6@osu.edu diet. Energy-corrected milk was greater (38.4 and 38.6 vs. $35.3 \mathrm{~kg} / \mathrm{d}$, respectively) for MPAA and HP than for the control. Cows fed MPAA had the greatest plasma concentrations of Met and the lowest concentrations of isoleucine, but lysine was not affected by treatment. Feeding additional MP (HMP or MPAA) reduced the concentrations of 3-methylhistidine in plasma, indicating reduced muscle breakdown. Diet effects on milk composition continued after cows were changed to a common diet in that cows fed MPAA the first 3 wk of lactation had greater concentration of milk protein for the entire experiment than cows fed HMP, and cows fed additional MP (HMP and MPAA) during phase 1 had greater concentrations of milk fat for the entire experiment. Increasing dietary protein and AA supply in early lactation had short-term effects on yield of energy-corrected milk and long-term effects on milk composition.

Key words: amino acid, metabolizable protein, carryover effects

\section{INTRODUCTION}

In the early postpartum period cows are unable to consume enough feed to meet demands of lactation and must rely on mobilization of body reserves to support lactation. Feeding these cows high-protein diets may limit protein mobilization, but will increase feed costs and can result in increased manure $\mathrm{N}$ excretion and environmental problems. When postpartum cows were fed a diet with $19 \%$ CP they produced more milk but did not consume more DM than cows fed a $16 \%$ CP diet (Komaragiri and Erdman, 1997), which led to similar degrees of body protein mobilization; however, in that study all the additional $\mathrm{CP}$ was provided by RUP. Increasing concentrations of RDP can increase digestibility of DM (Agle et al., 2010) and fiber (Lee et al., 2012b), resulting in greater DMI. Increasing both MP and RDP may lead to greater milk production and DMI, sparing body protein reserves in early lactation. Reduced mobilization of muscle tissue in early lactation may allow the cow to have additional reserves to 
mobilize after treatment ceases, thus increasing total milk production throughout peak lactation. Previous experiments showed that cows fed a diet with higher concentrations of energy and protein during the first 4 wk postpartum had greater milk yields after treatment ceased (Jørgensen et al., 2016).

An alternative to feeding high-protein diets in early lactation is to formulate diets for improved AA supply to the tissues. In traditional North American diets, corn silage and soybean meal are often major components, and those types of diets are limiting in lysine and methionine (NRC, 2001). Amino acid supplementation started in late gestation and continued during the early postpartum period has increased milk yields (Xu et al., 1998), FCM yields (Overton et al., 1996; $\mathrm{Xu}$ et al., 1998; Socha et al., 2005), and milk protein concentration and yield (Xu et al., 1998; Socha et al., 2005); however, because of experimental design, effects of prepartum supplementation could not be separated from postpartum supplementation effects. Increased milk protein production when AA supply was increased in early lactation could be (1) a direct effect of providing AA needed for milk protein synthesis; (2) an indirect effect caused by AA influences on cell signaling and regulation of protein synthesis within the mammary gland (Appuhamy et al., 2012); or (3) caused by increased mammary gland protein synthetic capacity.

We hypothesized that increasing the concentration of MP and RDP in early lactation would support greater milk and milk component production and stimulate DMI so that the effects would continue after treatments ceased. In addition, we hypothesized that similar effects would be observed when cows were fed a diet that provided less total protein but a better AA profile.

\section{MATERIALS AND METHODS}

\section{Cows and Diets}

All procedures involving the use of animals were approved by The Ohio State University Animal Care and Use Committee. Fifty-six Holstein cows were blocked by parity ( 6 blocks primiparous and 15 blocks multiparous) and calving date. Between 5 to $7 \mathrm{~d}$ before expected calving, cows were moved into individual box stalls and fed a common diet formulated to meet the nutrient requirements (NRC, 2001) of a late-gestation cow. Upon calving, cows were kept in box stalls for $2 \mathrm{~d}$ (fed the control diet plus ad libitum alfalfa hay; Table 1 ) and then moved to the tiestall barn and fed 1 of 3 diets (Tables 1 and 2). Cows were fed treatment diets for $21 \mathrm{~d}$ (23 DIM; phase 1) and then moved to a common freestall pen (phase 2), where they were fed the control diet for $63 \mathrm{~d}$ (86 DIM). In both phases, adequate TMR
Table 1. Experimental diets fed to cows in phase 1

\begin{tabular}{lccc}
\hline & & Diet $^{1}$ & \\
\cline { 2 - 4 } & & & \\
Ingredient, \% & Control & HMP & MPAA \\
\hline Corn silage & 40.0 & 40.0 & 40.0 \\
Alfalfa silage & 12.0 & 12.0 & 12.0 \\
Alfalfa hay & 5.00 & 5.00 & 5.00 \\
Whole cottonseed & 9.00 & 9.00 & 9.00 \\
AminoPlus & & 7.03 & - \\
Corn gluten meal & 2.00 & 1.62 & - \\
LysAAMet & - & - & 2.28 \\
Corn, ground & - & 14.0 & 15.7 \\
Soybean hulls & 15.7 & 1.85 & 4.39 \\
Soybean meal (48\% CP) & 4.43 & 7.05 & 8.72 \\
Hydrolyzed tallow & 8.95 & 0.49 & 0.49 \\
Trace mineral salt & 0.49 & 0.49 & 0.49 \\
Limestone & 0.49 & 1.01 & 0.76 \\
Dicalcium phosphate & 0.81 & 0.11 & 0.35 \\
Magnesium oxide & 0.35 & 0.07 & 0.07 \\
Selenium, 200 mg/kg & 0.16 & 0.16 & 0.16 \\
Biotin, 220 mg/kg & 0.16 & 0.34 & 0.34 \\
Zinpro 120 & 0.34 & 0.02 & 0.02 \\
Copper sulfate & 0.02 & 0.001 & 0.001 \\
Vitamin A (30,000 IU/g) & 0.001 & 0.02 & 0.02 \\
Vitamin D (3,000 IU/g) & 0.02 & 0.05 & 0.05 \\
Vitamin E (44 IU/g) & 0.05 & 0.08 & 0.08 \\
\hline I & 0.08 & & \\
\hline
\end{tabular}

${ }^{1}$ Diets were control $(16.5 \% \mathrm{CP})$, high metabolizable protein (HMP; $18.5 \% \mathrm{CP}$ ), and additional MP with a better AA profile (MPAA; $17.5 \% \mathrm{CP})$. The control diet was fed to all cows in phase 2 .

${ }^{2}$ AminoPlus, Ag Processing Inc., Omaha, NE.

${ }^{3}$ LysAAMet, Perdue Agribusiness, Salisbury, MD.

${ }^{4}$ Zinpro zinc methionine (Eden Prairie, MN).

was fed to achieve approximately $5 \%$ orts. While in tiestalls, feed delivered and refused for each individual cow was measured daily to determine DMI. Cow density in the freestall pen (contained 30 freestalls) was

Table 2. Nutrient composition of diets (DM basis)

\begin{tabular}{lccc}
\hline & & \multicolumn{2}{c}{ Diet $^{1}$} \\
Ingredient, \% of DM (unless \\
\cline { 2 - 4 } noted) & Control & HMP & MPAA \\
\hline DM & 50.3 & 50.2 & 49.7 \\
CP & 16.3 & 18.4 & 17.4 \\
RDP & & \\
Digestible RUP & 10.7 & 11.3 & 10.2 \\
Starch & 5.6 & 7.0 & 7.1 \\
NDF & 23.2 & 21.8 & 23.4 \\
Forage NDF & 35.7 & 33.5 & 34.8 \\
NE ${ }^{2}$ Mcal/kg & 24.2 & 24.3 & 24.3 \\
Mg & 1.68 & 1.69 & 1.68 \\
Ca & 0.28 & 0.29 & 0.26 \\
K & 0.96 & 1.05 & 0.94 \\
P & 1.65 & 1.71 & 1.57 \\
Met, ${ }^{2} \%$ of MP & 0.42 & 0.40 & 0.41 \\
Lys, ${ }^{2} \%$ of MP & 1.85 & 1.83 & 2.60 \\
His, ${ }^{2} \%$ of MP & 6.68 & 6.33 & 7.20 \\
\hline
\end{tabular}

${ }^{1}$ Diets were control $(16.5 \% \mathrm{CP})$, high metabolizable protein (HMP; $18.5 \% \mathrm{CP}$ ), and additional MP with a better AA profile (MPAA; $17.5 \% \mathrm{CP})$. The control diet was fed to all cows in phase 2 .

${ }^{2}$ Calculated using NRC (2001) with phase 1 treatment average DMI, milk yield and milk protein concentrations (Table 4 ). 
maintained at 30 cows by adding nonexperimental cows when necessary.

The 3 treatments were control, high metabolizable protein (HMP), and amino acid supplementation (MPAA). All diets were similar in composition except for CP, RDP, RUP, and AA (Table 1 and 2). Diets were formulated (NRC, 2001) assuming an average DMI of $17 \mathrm{~kg}$ during the first $23 \mathrm{DIM}$. The control diet was formulated to support $25 \mathrm{~kg} / \mathrm{d}$ of MP-allowable milk; the HMP diet was formulated to support $30 \mathrm{~kg} / \mathrm{d}$ of $\mathrm{MP}$-allowable milk and have a greater concentration of RDP because it can stimulate NDF digestibility (Lee et al., 2012b). The MPAA diet was formulated to support the same MP-allowable milk as HMP, but with similar RDP as the control and a Lys:Met closer to $3: 1$, as recommended by NRC (2001). The source of additional AA was a spray-dried blood meal product (LysAAMet, Perdue Agribusiness, Salisbury, MD). Formulation values used for the AA product were $78 \%$ of the DM as digestible RUP, and 8.3 and $5.4 \%$ of the digestible RUP as Lys and Met, respectively (data provided by Perdue Agribusiness).

\section{Sampling and Measurements}

Cows were weighed 2 consecutive days after moving into tiestalls (d 1 and 2 of experiment), d 19 and 20 (shortly before cows left the tiestalls), and at the end of the trial ( $\mathrm{d} 83$ and 84 ). The 2 consecutive weights were averaged unless the difference was $>25 \mathrm{~kg}$, in which case the cows were weighed on a third day and the 3 BW were averaged. Body condition (Edmonson et al., 1989) was evaluated by 2 independent scorers (scores were averaged) on approximately the same days as cows were weighed.

Silages, hay, and concentrate mixes were sampled weekly and composited monthly (samples were kept frozen at $-20^{\circ} \mathrm{C}$ until analysis). A subsample of the weekly silage samples was assayed for DM using a forced-air oven at $100^{\circ} \mathrm{C}$ for $48 \mathrm{~h}$ to adjust diets for changes in DM. Monthly composite samples of forages and concentrate mixes were dried in a forced-air oven at $55^{\circ} \mathrm{C}$ for $48 \mathrm{~h}$ and ground through a $1-\mathrm{mm}$ screen (Wiley Mill, Arthur A. Thomas, Philadelphia, PA). The dried and ground samples were analyzed in duplicate for N (AOAC International, 2000; 984.13.4.2.09) using the Kjeldahl method (Foss Tecator, Eden Prairie, MN), NDF (NDF Method 6; Ankom200 Fiber Analyzer, Ankom Technology, Fairport, NY) using sodium sulfite and $\alpha$-amylase (Sigma A3306, Sigma Diagnostics, St. Louis, MO), long-chain fatty acids (Weiss and Wyatt, $2003)$, ash $\left(600^{\circ} \mathrm{C}\right)$, and minerals (AOAC International, 2000; 985.01; Cumberland Valley Analytical Services,
Hagerstown, MD). Concentrate and corn silage samples were assayed for starch (Weiss and Wyatt, 2000). Cottonseed was sampled once monthly and combined into 2-mo composites $(\mathrm{n}=4)$ and analyzed for DM, $\mathrm{CP}, \mathrm{NDF}$, ash, and minerals. In total, we compiled 9 monthly composite samples of forages and the control concentrate mix but 7 monthly composite samples for the HMP and MPAA concentrate mixes, as they were not used in phase 2 .

Approximately 4 mo into the experiment, the source of alfalfa silage changed and diets had to be reformulated; inclusion rates of the concentrate mix were increased 2 percentage units and that of alfalfa silage was reduced 2 units. Slight adjustments were also made to inclusion rates of soybean meal, soybean hulls, and corn grain to maintain nutrient composition of the diets. The data shown in Tables 1 and 2 reflect the weighted average of the diets. During phase 1, feed refusals were weighed daily and samples were taken for each cow once weekly for the first 2 wk. Samples were assayed for DM and then composited within cow and assayed for $\mathrm{CP}$ and NDF to evaluate sorting. In general, composition of refusals reflected dietary composition.

Approximately $6 \mathrm{~h}$ postfeeding on d 8, 15 (phase 1), and 31 (phase 2; i.e., $10 \mathrm{~d}$ after moving into the freestalls), a blood sample was taken from the tail vein into heparinized Vacutainers (\#366480, BD \& Co., Franklin Lakes, NJ). Samples were kept on ice until plasma was harvested (centrifuged at $4^{\circ} \mathrm{C}, 2,420$ $\times g$ for $20 \mathrm{~min}$ ) and frozen at $-20^{\circ} \mathrm{C}$ until assayed. Plasma samples (all days) were assayed in duplicate for BHB (Kit: 2440-058, Stanbio Laboratories, Boerne, TX) and fatty acids (d 8 and 15; Kit: 999-34691, Wako Diagnostics, Mountain View, CA). Plasma taken on d 15 from 28 multiparous cows, representing 8 complete blocks and 2 incomplete blocks (samples from a control cow and an HMP cow were not assayed because of hemolysis), were assayed for AA, 1-methylhistidine, and 3-methylhistidine at the Amino Acid Lab of University of California-Davis College of Veterinary Medicine (Kim et al., 1995).

Urine spot samples were collected via vulva stimulation $6 \mathrm{~h}$ after feeding on $\mathrm{d} 8,15$, and 31. Samples were filtered through a paper towel and frozen at $-20^{\circ} \mathrm{C}$ until analysis. The samples were thawed in a $39^{\circ} \mathrm{C}$ water bath for $20 \mathrm{~min}$ and assayed in quadruplet for creatinine (kit: 500701, Cayman Chemical, Ann Arbor, MI) according to package instructions and in duplicate for $\mathrm{N}$ using the method mentioned previously. Urine volume and urinary $\mathrm{N}$ excretion was then estimated (Valadares et al., 1999).

Cows were milked twice daily at 0200 and $1300 \mathrm{~h}$ and sampled (a.m. and p.m.) once weekly and analyzed for 
fat, protein, lactose (B2000 Infrared Analyzer, Bentley Instruments, Chaska MN), and MUN (Skalar SAN Plus segmented flow analyzer, Skalar Inc., Norcross, GA) by DHI Cooperative Inc. (Columbus, OH). Additional milk samples (a.m. only) were taken on d 8 and 20 (phase 1) and d 31(phase 2) for milk fatty acid analysis using a 2-step procedure for methylation (Palmquist and Jenkins, 2003).

\section{Statistical Analysis}

Seven multiparous cows (2 Control, $2 \mathrm{HP}$, and 3 MPAA) were removed from the trial due to displaced abomasum that occurred in phase 1 of the experiment. Data from those cows were not used. In total, 21 primiparous and 35 multiparous cows finished the trial $($ control $=19, \mathrm{HP}=18, \mathrm{MPAA}=19)$. Data were analyzed using the MIXED procedure of SAS (version 9.4, SAS Institute Inc., Cary, NC) using the following model:

$$
\begin{gathered}
\mathrm{Y}_{\mathrm{ijklm}}=\mu \\
+\mathrm{D}_{\mathrm{i}}+\mathrm{P}_{\mathrm{j}}+\mathrm{B}_{\mathrm{k}(\mathrm{j})}+\mathrm{T}_{\mathrm{l}}+\mathrm{DP}_{\mathrm{ij}}+\mathrm{DT}_{\mathrm{il}} \\
+\mathrm{DTP}_{\mathrm{ijl}}+\mathrm{c}_{\mathrm{m}}(\mathrm{k})+\mathrm{e}_{\mathrm{ijklm}},
\end{gathered}
$$

where $\mathrm{Y}_{\mathrm{ijklm}}=$ dependent variable; $\mu=$ population mean; $\mathrm{Di}=$ fixed effect of diet; $\mathrm{P}_{\mathrm{j}}=$ fixed effect of parity; $B_{k}=$ random effect of block within parity; $T_{1}$ $=$ fixed effect of time (repeated measure); $\mathrm{DP}_{\mathrm{ij}}=\operatorname{diet}$ by parity interaction; $\mathrm{DT}_{\mathrm{ikl}}=$ diet by time interaction; $\mathrm{DTP}_{\mathrm{ijk}}=$ diet by parity by time interaction; $\mathrm{c}_{\mathrm{m}}=$ random effect of cow within block; and $e_{\mathrm{ijklm}}=$ residual error.

For milk production and DMI, time was expressed in days in phase 1 because milk production and DMI were increasing rapidly during that time. Time was expressed in weeks for phase 2 because the changes in DMI and milk yield were not as dynamic. For blood, urine, and milk fatty acid data, time represented the 2 sampling days in phase 1 . For measures that were not repeated (e.g., plasma AA), the same model was used except time and time interactions were removed. A priori contrasts were used to evaluate the effects of additional protein (i.e., control vs. HMP + MPAA) and AA supplementation (i.e., HMP vs MPAA). Production data were analyzed for each phase separately and for both phases combined.

\section{RESULTS AND DISCUSSION}

\section{Diets}

Using treatment average DMI, milk yields, and milk composition in phase 1, protein requirements and sup- ply (NRC, 2001) were calculated (Table 3). The control diet was 15\% deficient in MP and 29\% deficient in digestible RUP, but essentially met the RDP requirement. The HMP diet was 5\% deficient in MP, 9\% deficient in digestible RUP, but had a $10 \%$ excess of RDP. The MPAA diet was also 5\% deficient in MP, digestible RUP was $15 \%$ deficient, and the RDP requirement was essentially met. A re-evaluation (Schwab et al., 2009) of the AA recommendations of NRC (2001) indicated that milk protein concentration was maximized when digestible Lys and Met were 6.8 and $2.3 \%$ of the MP flow to the duodenum, respectively. Based on those standards, the MPAA diet provided excess Lys and Met, but the control and HMP were about $25 \%$ low in Met (Table 3). The control and HMP diets were about 2 and $7 \%$ low in Lys, respectively. The MPAA diet provided more histidine than the other diets, but NRC (2001) did not provide recommendations for that AA. Greater than estimated milk and milk protein yields for all treatments, but especially for the control diet, indicate either the NRC model under predicted supply or overestimated requirements of MP in early lactation. Lee et al. (2012b) determined that the NRC (2001) severely underpredicts milk production in MP-deficient diets. Another likely explanation is that body reserves of protein were mobilized to support milk yield (Komaragiri and Erdman, 1997).

\section{Phase 1}

No parity by treatment interactions were observed and parity effects were as expected and will not be discussed.

Table 3. NRC (2001) protein and AA requirements and supply ${ }^{1}$

\begin{tabular}{lccc}
\hline & \multicolumn{3}{c}{ Diet $^{2}$} \\
\cline { 2 - 4 } Item, g/d (unless noted) & Control & HMP & MPAA \\
\hline MP supply & 1,894 & 2,161 & 2,165 \\
MP requirement & 2,237 & 2,269 & 2,280 \\
MP balance & -343 & -108 & -115 \\
RDP required & 1,816 & 1,858 & 1,851 \\
RDP supply & 1,845 & 2,053 & 1,840 \\
RDP balance & 29 & 195 & -11 \\
RUP required & 1,415 & 1,384 & 1,440 \\
RUP supply & 1,034 & 1,251 & 1,264 \\
RUP balance & -381 & -133 & -176 \\
Digestible Lys, \% MP & 6.7 & 6.3 & 7.2 \\
Digestible Met, \% MP & 1.9 & 1.8 & 2.6 \\
Digestible His, \% MP & 2.3 & 2.2 & 2.9 \\
\hline
\end{tabular}

${ }^{1}$ Calculated using NRC (2001) with phase 1 treatment average DMI, milk production, and milk components.

${ }^{2}$ Diets were control $(16.5 \% \mathrm{CP})$, high metabolizable protein (HMP; 18.5\% CP), and additional MP with a better AA profile (MPAA; $17.5 \% \mathrm{CP})$. 
Production Measures. Treatment did not affect DMI or milk yield (Table 4), but a treatment by day interaction was observed for both measures $(P<0.01)$. Linearly increasing concentrations of $\mathrm{CP}$ linearly increased DMI in midlactation cows (Cyriac et al., 2008), and we observed a similar increase in DMI for the higher-protein diets during the first $5 \mathrm{~d}$ of the trial (Figure 1). From the sixth day of the experiment, DMI for all treatments were similar. Cows undergo substantial changes during the first few weeks of lactation, including a major switch in diet (high fiber, low energy to moderate fiber, high energy), changes in rumen characteristics including increased volume and increased fermentation and altered fermentation acid profile, and rapidly increasing energy demands. Additionally, these treatments were imposed during a period when DMI is normally increasing very rapidly. All these factors may have a greater effect on DMI than protein supply. Energy-corrected milk, MUN, and yield and concentration of milk fat were greater $(P<0.05)$ for cows fed the higher-protein diets, but no treatment by week interactions were observed $(P>0.3)$. Amino acid supplementation (i.e., MPAA vs. HMP) increased milk protein percentage $(P<0.04)$ and tended to reduce MUN ( $P$ $<0.09$ ); this change suggested a better protein balance (synthesis minus degradation or catabolism). Changes in BCS and BW were not different among treatments (Table 4).
The increased milk fat yield and concomitant increase in ECM when higher-protein diets were fed could be a result of increased mobilization of body fat. However, the lack of any effects of higher protein on changes in BCS and BW (Table 4), plasma fatty acid concentrations (discussed below), and concentrations of longchain fatty acids in milk (discussed below) does not support increased fat mobilization by cows fed higherprotein diets. Based on a meta-analysis, increasing MP supply is associated with increased milk fat percentage and yield (Daniel et al., 2016), but in that meta-analysis MP was also associated with increased DMI, which we did not observe in phase 1. A substantial AA imbalance can increase milk fat concentration and yield (Weekes et al., 2006), as can supplemental protected Met and methionine analogs (Zanton et al., 2014). Methionine is important for choline synthesis, which is a major component of phosphatidylcholine used in lipoprotein synthesis for transport of triglycerides (Wang et al., 2010). Blocking the methionine-driven synthesis of choline has decreased milk fat concentration (Guretzky et al., 2006). However, Met supply likely is not the only explanation, as no differences in milk fat yield or concentrations were observed between HMP and MPAA treatments. Socha et al. (2005) fed rumen-protected Lys and Met in diets containing 16 and $18.5 \% \mathrm{CP}$ to cows immediately postpartum; increased dietary protein did not affect ECM yield, but it was increased when pro-

Table 4. Production measurements for the first $3 \mathrm{wk}$ of lactation when cows were fed diets differing in MP and AA profiles ${ }^{1}$

\begin{tabular}{|c|c|c|c|c|c|c|}
\hline \multirow[b]{2}{*}{ Item } & \multicolumn{3}{|c|}{ Diet $^{2}$} & \multirow[b]{2}{*}{ SEM } & \multicolumn{2}{|c|}{$P$-value ${ }^{3}$} \\
\hline & Control & HMP & MPAA & & MP & AA \\
\hline DMI, kg/d & 17.8 & 18.0 & 18.5 & 0.45 & $<0.46$ & $<0.44$ \\
\hline $\mathrm{BW}, \mathrm{kg}$ & 645 & 647 & 643 & 13.5 & $<0.95$ & $<0.85$ \\
\hline BW change, $\mathrm{kg} / 21 \mathrm{~d}$ & -24.2 & -17.7 & -24.7 & 4.11 & $<0.54$ & $<0.23$ \\
\hline BCS & 3.3 & 3.4 & 3.4 & 0.13 & $<0.56$ & $<0.92$ \\
\hline BCS change/21 d & -0.46 & -0.39 & -0.52 & 0.10 & $<0.95$ & $<0.36$ \\
\hline Milk, kg/d & 33.6 & 34.7 & 33.2 & 1.09 & $<0.78$ & $<0.33$ \\
\hline $\mathrm{ECM}^{4}{ }^{4} \mathrm{~kg} / \mathrm{d}$ & 35.3 & 38.6 & 38.4 & 1.35 & $<0.05$ & $<0.95$ \\
\hline Milk fat, $\%$ & 3.80 & 4.21 & 4.51 & 0.152 & $<0.003$ & $<0.16$ \\
\hline Milk fat, $\mathrm{kg} / \mathrm{d}$ & 1.26 & 1.46 & 1.50 & 0.080 & $<0.01$ & $<0.73$ \\
\hline Milk protein, \% & 3.17 & 3.17 & 3.30 & 0.047 & $<0.26$ & $<0.04$ \\
\hline Milk protein, $\mathrm{kg} / \mathrm{d}$ & 1.04 & 1.09 & 1.08 & 0.032 & $<0.34$ & $<0.82$ \\
\hline Milk lactose, \% & 4.87 & 4.82 & 4.84 & 0.032 & $<0.29$ & $<0.64$ \\
\hline Milk lactose, $\mathrm{kg} / \mathrm{d}$ & 1.63 & 1.66 & 1.60 & 0.050 & $<0.99$ & $<0.33$ \\
\hline MUN, mg/100 mL & 11.7 & 14.2 & 12.6 & 0.64 & $<0.01$ & $<0.02$ \\
\hline
\end{tabular}

${ }^{1}$ All measures were affected $(P<0.05)$ by week (except MUN) and parity (except MUN and milk fat percentage). No week by treatment interactions were observed.

${ }^{2}$ Diets were control $(16.5 \% \mathrm{CP})$, high metabolizable protein (HMP; $\left.18.5 \% \mathrm{CP}\right)$, and additional MP with a better AA profile (MPAA; $17.5 \% \mathrm{CP}$ ).

${ }^{3} \mathrm{MP}=$ contrast evaluating effect of increased MP (control vs. HMP + MPAA); AA = contrast evaluating effect of altered AA profile with equal MP (HMP vs. MPAA).

${ }^{4} \mathrm{ECM}=0.323 \times \mathrm{kg}$ of milk $+12.82 \times \mathrm{kg}$ of milk fat $+7.13 \times$ milk protein (Tyrrell and Reid, 1965). 


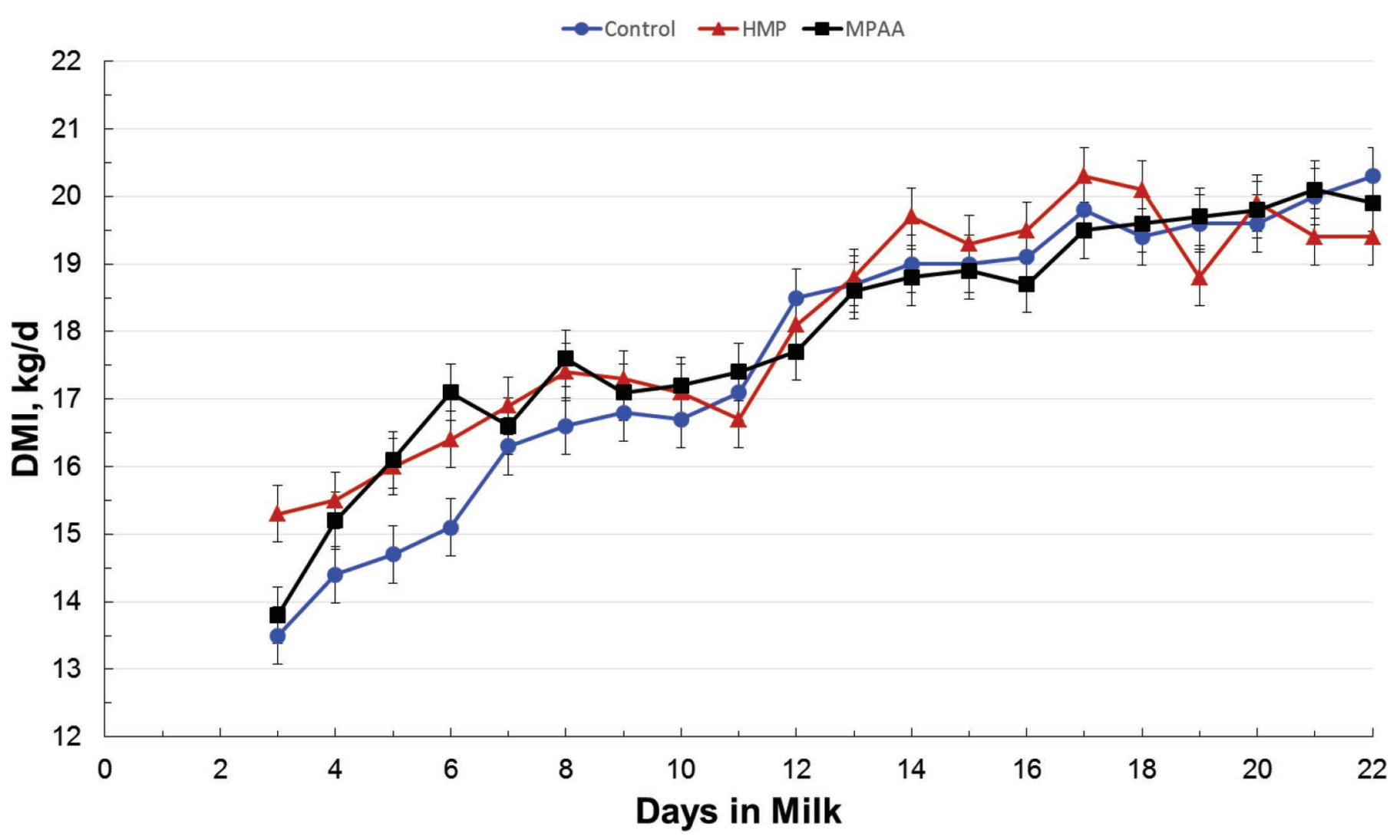

Figure 1. Effect of feeding diets with different concentrations of MP and AA on DMI during the first 3 wk of lactation. Diets were control (circles, blue, 16.5\% CP), high MP (HMP; triangles, red, 18.5\% CP), and intermediate MP formulated to provide a good balance of AA (MPAA; squares, black; $17.5 \% \mathrm{CP})$. Day and treatment $\times$ day interaction affected DMI $(P<0.05)$. Error bars indicate standard error of the mean. Color version available online.

tected AA were fed. In addition, milk fat concentration was not increased by feeding higher-protein diets and was increased only when protected Met was the sole AA supplemented. The increased protein concentration by cows fed MPAA agrees with some (Donkin et al., 1989; Noftsger et al., 2005; Socha et al., 2005) but not all (Papas et al., 1984; Chow et al., 1990) studies that evaluated supplemental protected AA. Treatment effects on MUN reflected concentrations of dietary CP.
Nitrogen Intake and Estimated Excretion. Urine volume estimated using creatinine (Valadares et al., 1999) was not affected by treatment (Table 5), although feeding higher-protein diets to cows in later lactation usually increases urine volume when measured by total collection (Weiss et al., 2009). Urinary $\mathrm{N}$ excretion was increased when higher-protein diets were fed $(P<0.01)$, but were lower for MPAA compared with HMP $(P<0.01)$. The MPAA effect could

Table 5. Effect of diet on estimated excretion of urinary $\mathrm{N}^{1}$

\begin{tabular}{|c|c|c|c|c|c|c|}
\hline \multirow[b]{2}{*}{ Item } & \multicolumn{3}{|c|}{ Diet $^{2}$} & \multirow[b]{2}{*}{ SEM } & \multicolumn{2}{|c|}{$P$-value ${ }^{3}$} \\
\hline & Control & HMP & MPAA & & MP & AA \\
\hline $\mathrm{N}$ intake, $\mathrm{g} / \mathrm{d}$ & 393 & 469 & 448 & 12.8 & $<0.01$ & $<0.24$ \\
\hline Urine volume, $\mathrm{L} / \mathrm{d}$ & 21.2 & 22.8 & 20.5 & 1.74 & $<0.82$ & $<0.33$ \\
\hline Urinary $\mathrm{N}, \mathrm{g} / \mathrm{d}$ & 168 & 220 & 186 & 8.41 & $<0.01$ & $<0.01$ \\
\hline Urinary $\mathrm{N}, \% \mathrm{~N}$ intake & 43.2 & 47.2 & 42.5 & 2.10 & $<0.48$ & $<0.11$ \\
\hline
\end{tabular}

${ }^{1}$ All measures were affected by parity $(P<0.05)$.

${ }^{2}$ Diets were control $(16.5 \% \mathrm{CP})$, high metabolizable protein (HMP; $\left.18.5 \% \mathrm{CP}\right)$, and additional MP with a better AA profile (MPAA; $17.5 \% \mathrm{CP}$ ).

${ }^{3} \mathrm{MP}=$ contrast evaluating effect of increased MP (control vs. HMP + MPAA); AA = contrast evaluating effect of altered AA profile with equal MP (HMP vs. MPAA). 
Table 6. Effect of diet on concentrations $(\mathrm{nmol} / \mathrm{mL}$ ) of AA in plasma from a subset of cows on d 15 (phase 1)

\begin{tabular}{|c|c|c|c|c|c|c|}
\hline \multirow[b]{2}{*}{$\mathrm{AA}$} & \multicolumn{3}{|c|}{ Diet $^{1}$} & \multirow[b]{2}{*}{ SEM } & \multicolumn{2}{|c|}{$P$-value ${ }^{2}$} \\
\hline & Control & HMP & MPAA & & MP & AA \\
\hline Arginine & 61.9 & 62.2 & 59.1 & 4.75 & $<0.79$ & $<0.56$ \\
\hline Histidine & 40.7 & 43.2 & 54.5 & 2.93 & $<0.02$ & $<0.01$ \\
\hline Methionine & 17.1 & 19.6 & 39.4 & 3.62 & $<0.01$ & $<0.01$ \\
\hline Lysine & 61.5 & 59.5 & 62.6 & 4.70 & $<0.93$ & $<0.56$ \\
\hline Isoleucine & 125.8 & 124.3 & 83.4 & 11.4 & $<0.08$ & $<0.01$ \\
\hline Leucine & 116.5 & 162.5 & 113.9 & 14.2 & $<0.13$ & $<0.01$ \\
\hline Phenylalanine & 44.9 & 51.2 & 44.0 & 3.21 & $<0.40$ & $<0.06$ \\
\hline Threonine & 91.1 & 86.3 & 94.0 & 7.37 & $<0.91$ & $<0.41$ \\
\hline Valine & 203.2 & 211.8 & 194.9 & 18.5 & $<0.99$ & $<0.45$ \\
\hline 1-Methylhistidine & 11.1 & 11.4 & 8.7 & 0.77 & $<0.23$ & $<0.01$ \\
\hline 3-Methylhistidine & 5.80 & 4.50 & 4.55 & 0.49 & $<0.03$ & $<0.94$ \\
\hline Total EAA & 792.9 & 853.1 & 776.4 & 58.5 & $<0.70$ & $<0.26$ \\
\hline Total NEAA & $1,086.7$ & $1,042.4$ & $1,048.7$ & 45.8 & $<0.38$ & $<0.91$ \\
\hline
\end{tabular}

${ }^{1}$ Diets were control $(16.5 \% \mathrm{CP})$, high metabolizable protein (HMP; $\left.18.5 \% \mathrm{CP}\right)$, and additional MP with a better AA profile (MPAA; $17.5 \% \mathrm{CP}$ ).

${ }^{2} \mathrm{MP}=$ contrast evaluating effect of increased metabolizable protein (Control vs. HMP + MPAA); AA = contrast evaluating effect of altered AA profile with equal MP (HMP vs. MPAA).

be caused by differences in $\mathrm{N}$ intake; however, urinary $\mathrm{N}$ as a percentage of $\mathrm{N}$ intake tended to be lower $(P$ $<0.11)$ for MPAA treatment compared with HMP diet (Table 5), suggesting improved efficiency of using dietary $\mathrm{N}$.

Blood Metabolite Concentrations. Concentrations of plasma fatty acids decreased between $\mathrm{d} 8$ and 15 (235 vs. $195 \mathrm{mEq} / \mathrm{L} ; \mathrm{SEM}=17.5 ; P<0.02$ ), but no treatment contrasts were significant $(P>0.25)$ and no treatment by day interaction was observed $(P>0.40)$. Average fatty acid concentrations were 192, 245, and $208 \mathrm{mEq} / \mathrm{L}$ for control, HMP, and MPAA, respectively. Concentrations of BHB were not affected by treatment contrasts or time by treatment interactions but were higher in multiparous cows compared with firstlactation cows (513 vs. $860 \mu \mathrm{mol} / \mathrm{L}$ for first-lactation vs. older cows; $\mathrm{SEM}=57.0 ; P<0.01)$. For all cows, average BHB for d 8 and 15 were 661 and $711 \mu \mathrm{mol} / \mathrm{L}$. In phase 2 (when cows were fed a common diet), firstlactation cows had lower BHB concentrations (468 vs. $624 \mu \mathrm{mol} / \mathrm{L} ; \mathrm{SEM}=53.0 ; P<0.03)$ but no significant treatment contrasts or interactions were observed (590, 542 , and $507 \mu \mathrm{mol} / \mathrm{L}$ for control, HMP and MPAA, respectively; $\mathrm{SEM}=61.2 ; P>0.35)$. Concentrations of BHB $>1,200 \mu \mathrm{mol} / \mathrm{L}$ can indicate subclinical ketosis (Duffield et al., 1998); 4 multiparous cows fed the control diet and 3 cows fed the HMP diet had plasma BHB levels $>1,200 \mu \mathrm{mol} / \mathrm{L}$. Incidence of subclinical ketosis was not affected by treatment (chi-square; $P=0.14$ ); however, this study may have lacked adequate statistical power to accurately evaluate health events.

Plasma AA Concentrations. Feeding higher-protein diets increased $(P<0.02)$ plasma concentrations of His and Met, but those effects were caused mainly by the MPAA diet (Table 6). The elevated concentrations of plasma Met clearly support increased supply of that AA when cows were fed MPAA; however, plasma concentration of Lys was not affected by treatment. This could mean that supply was not increased; however, plasma AA concentrations only increase when supply exceeds requirement (Clark, 1975). More Lys may have been taken up by the mammary gland of cows fed MPAA, as indicated by increased milk protein concentrations. The reason why MPAA treatment did not increase plasma Lys is unknown, but similar results are often observed when supplemental protected Lys and Met are fed (Lee et al., 2012a, 2015). Feeding MPAA reduced $(P<0.01)$ plasma concentration of Ile similar to other studies in which Lys and Met were supplemented (Blum et al., 1999; Appuhamy et al., 2011), suggesting increased utilization of Ile by tissues and that Ile may be limiting.

Plasma concentrations of 3-methylhistidine can be an index of muscle catabolism (Blum et al., 1985), and its concentration was greater $(P<0.03)$ in cows fed the control diet than cows fed the higher-protein diets. Skeletal muscle serves as the major protein depot and can serve as a protein reserve in dairy cattle. Because protein requirements are high in very early lactation, cows mobilize muscle tissue to meet protein requirements. This breakdown of muscle is considered important in early lactation because it provides AA for milk protein synthesis and gluconeogenesis (Botts et al., 1979; Blum et al., 1985). Higher dietary MP appeared to reduce muscle catabolism in early lactation.

Milk Fatty Acid Concentrations. We noted significant day and treatment by day interactions for various milk fatty acids; however, no discernable pat- 
Table 7 . Effects of treatment on milk fatty acid concentrations ( $\mathrm{g} / \mathrm{kg}$ of total fatty acids) in phase $1^{1}$

\begin{tabular}{|c|c|c|c|c|c|c|}
\hline \multirow[b]{2}{*}{ Fatty acid ${ }^{2}$} & \multicolumn{3}{|c|}{ Diet $^{3}$} & \multirow[b]{2}{*}{ SEM } & \multicolumn{2}{|c|}{$P$-value ${ }^{4}$} \\
\hline & Control & HMP & MPAA & & MP & $\mathrm{AA}$ \\
\hline SCFA & 217.6 & 212.5 & 209.4 & 11.00 & $<0.60$ & $<0.82$ \\
\hline OBCFA & 34.5 & 27.1 & 29.4 & 1.18 & $<0.01$ & $<0.09$ \\
\hline $15: 0$ & 10.9 & 7.1 & 7.9 & 0.70 & $<0.01$ & $<0.27$ \\
\hline $17: 0$ & 7.2 & 7.1 & 7.3 & 0.19 & $<1.00$ & $<0.47$ \\
\hline $17: 1$ & 2.6 & 3.4 & 3.4 & 0.22 & $<0.01$ & $<0.83$ \\
\hline LCFA & 436.1 & 455.7 & 452.2 & 16.76 & $<0.38$ & $<0.86$ \\
\hline $18: 0$ & 128.7 & 142.9 & 137.2 & 5.37 & $<0.07$ & $<0.40$ \\
\hline trans- 6 and $-8,18: 1$ & 5.6 & 3.8 & 4.2 & 0.23 & $<0.01$ & $<0.18$ \\
\hline trans-9 18:1 & 3.5 & 2.7 & 2.9 & 0.12 & $<0.01$ & $<0.11$ \\
\hline trans-10 18:1 & 18.1 & 7.2 & 8.2 & 2.09 & $<0.01$ & $<0.72$ \\
\hline trans-11 18:1 & 25.3 & 19.3 & 24.4 & 2.43 & $<0.15$ & $<0.07$ \\
\hline trans-12 18:1 & 6.7 & 4.7 & 5.1 & 0.36 & $<0.01$ & $<0.36$ \\
\hline cis-9 18:1 & 210.5 & 236.7 & 233.3 & 13.74 & $<0.13$ & $<0.84$ \\
\hline cis-11 18:1 & 9.1 & 9.3 & 12.0 & 3.09 & $<0.63$ & $<0.49$ \\
\hline $18: 2$ & 29.8 & 26.3 & 24.8 & 1.12 & $<0.01$ & $<0.27$ \\
\hline $20: 0$ & 1.4 & 1.4 & 1.4 & 0.075 & $<0.95$ & $<0.29$ \\
\hline $20: 1$ & 0.47 & 0.52 & 0.47 & 0.029 & $<0.36$ & $<0.15$ \\
\hline $18: 3$ & 4.0 & 3.6 & 3.6 & 0.20 & $<0.10$ & $<0.88$ \\
\hline cis-9,trans-11 CLA & 6.9 & 5.4 & 5.9 & 0.59 & $<0.02$ & $<0.38$ \\
\hline trans-10,cis-12 CLA & 0.22 & 0.16 & 0.17 & 0.018 & $<0.01$ & $<0.63$ \\
\hline
\end{tabular}

${ }^{1}$ There were no parity or treatment by day interactions. Data are average of samples taken on d 8, 15, and 20 . ${ }^{2}$ Number of carbons:number of double bonds. SCFA = total short-chain fatty acids; OBCFA = total odd- and branched-chain fatty acids; LCFA = total long-chain fatty acids.

${ }^{3}$ Diets were control $(16.5 \% \mathrm{CP})$, high metabolizable protein (HMP; $18.5 \% \mathrm{CP}$ ), and additional MP with a better AA profile (MPAA; $17.5 \% \mathrm{CP}$ ).

${ }^{4} \mathrm{MP}=$ contrast evaluating effect of increased MP (control vs. HMP + MPAA); AA = contrast evaluating effect of altered AA profile with equal MP (HMP vs. MPAA).

terns were observed (data not shown). Feeding higherprotein diets increased $(P<0.01)$ concentrations of several odd- and branched-chain fatty acids (Table 7 ), but few differences between HMP and MPAA were observed. Odd- and branched-chain fatty acids reflect rumen fermentation and rumen microbial populations and microbial protein, but some postabsorptive synthesis occurs (Vlaeminck et al., 2006; Fievez et al., 2012; French et al., 2012). Cows fed higher-protein diets also had reduced concentrations of several trans fatty acids, including trans-10 18:1 and trans-10,cis-12 18:2. High concentrations of those 2 fatty acids are related to lower concentrations of milk fat (Bauman and Griinari, 2001). Leonardi et al. (2003) observed that concentrations of trans-10,cis-12 CLA tended to decrease when dietary CP increased from 16.1 to $18.9 \%$. Changes in milk fatty acids suggest that higher-protein diets altered rumen fermentation, which may have contributed to increased milk fat production.

\section{Phase 2 and Total Experiment}

The diet fed in early lactation continued to affect milk fat and protein concentrations after cows were switched to a common diet (Table 8), but no other carryover effects were observed during phase 2. Milk fat was greater for cows that were previously fed higherprotein diets $(P<0.06)$, and cows previously fed the MPAA diet had greater milk fat $(P<0.03)$ and protein concentrations $(P<0.08)$. The reasons for these carryover effects are not clear. Increasing dietary $\mathrm{CP}$ from 11.4 to $17.3 \%$ for the first 150 DIM increased milk fat and protein yields, and the effect on milk protein yield (but not fat) was maintained during the following 150 d when all cows were fed a $14.4 \% \mathrm{CP}$ diet (Law et al., 2009). Increased nutrient intake during early lactation $(<5$ wk of lactation) by either increasing concentrate feeding or increased pasture allowance has resulted in increased milk yield and milk component yields later in lactation after treatments ceased (Jørgensen et al., 2016). Because those treatments also increased DMI while treatments were imposed, higher DMI could have been maintained after treatments ceased (DMI during carryover period was not reported). Increased DMI could have caused the carryover effects on production measures. However, in our study, DMI was not affected during the treatment period and because of group feeding we do not know if DMI differed between groups during phase 2 .

Essentially no differences in milk fatty acid profile were observed between treatments after cows were fed a common diet (data not shown). When production 
Table 8. Effect of phase 1 treatments on milk production and milk components during phase 2 (wk 4 to 12 of lactation $)^{1}$

\begin{tabular}{|c|c|c|c|c|c|c|}
\hline \multirow[b]{2}{*}{ Item } & \multicolumn{3}{|c|}{ Diet $^{2}$} & \multirow[b]{2}{*}{ SEM } & \multicolumn{2}{|c|}{$P$-value ${ }^{3}$} \\
\hline & Control & HMP & MPAA & & MP & AA \\
\hline BW change, ${ }^{4} \mathrm{~kg}$ & 27.3 & 32.6 & 20.7 & 5.97 & $<0.93$ & $<0.17$ \\
\hline BCS change $^{4}$ & 0.00 & -0.18 & -0.12 & 0.10 & $<0.20$ & $<0.69$ \\
\hline Milk yield, $\mathrm{kg} / \mathrm{d}$ & 38.8 & 39.3 & 37.6 & 1.51 & $<0.85$ & $<0.41$ \\
\hline $\mathrm{ECM}^{5}{ }^{5} \mathrm{~kg} / \mathrm{d}$ & 39.5 & 39.9 & 39.8 & 1.43 & $<0.84$ & $<0.96$ \\
\hline Milk protein, \% & 2.90 & 2.85 & 2.95 & 0.04 & $<1.00$ & $<0.08$ \\
\hline Milk protein, $\mathrm{kg} / \mathrm{d}$ & 1.13 & 1.12 & 1.10 & 0.04 & $<0.62$ & $<0.65$ \\
\hline Milk fat, $\%$ & 3.49 & 3.58 & 3.94 & 0.11 & $<0.06$ & $<0.03$ \\
\hline Milk fat, $\mathrm{kg} / \mathrm{d}$ & 1.38 & 1.41 & 1.47 & 0.06 & $<0.45$ & $<0.53$ \\
\hline Lactose, $\%$ & 4.89 & 4.84 & 4.92 & 0.04 & $<0.76$ & $<0.10$ \\
\hline Lactose, $\mathrm{kg} / \mathrm{d}$ & 1.92 & 1.91 & 1.85 & 0.07 & $<0.64$ & $<0.54$ \\
\hline MUN, mg/100 mL & 14.2 & 13.5 & 14.2 & 0.64 & $<0.60$ & $<0.28$ \\
\hline
\end{tabular}

${ }^{1}$ No treatment by time interactions. All measures except milk fat percentage and MUN were affected by parity $(P<0.05)$. Week affected $(P<0.05)$ milk yield, milk protein and fat percentage, milk fat yield, and MUN.

${ }^{2}$ Diets were control $(16.5 \% \mathrm{CP})$, high metabolizable protein (HMP; $\left.18.5 \% \mathrm{CP}\right)$, and additional MP with a better AA profile (MPAA; $17.5 \% \mathrm{CP}$ ).

${ }^{3} \mathrm{MP}=$ contrast evaluating effect of increased MP (control vs. HMP + MPAA); AA = contrast evaluating effect of altered AA profile with equal MP (HMP vs. MPAA).

${ }^{4} \mathrm{BW}$ and BCS change per $8 \mathrm{wk}$.

${ }^{5} \mathrm{ECM}=0.323 \times \mathrm{kg}$ of milk $+12.82 \times \mathrm{kg}$ of milk fat $+7.13 \times$ milk protein (Tyrrell and Reid, 1965).

measures for phase 1 and 2 were combined, no treatment effects were observed for yields of milk, ECM, protein, and fat (Table 9). However concentrations of milk fat were greater in cows fed the higher-protein diets $(P<0.02)$ and milk fat. Protein concentrations tended to be greater for cows fed MPAA than those fed HMP, but this could be attributed to the numerically lower milk yield in MPAA. The absence of carryover effects in other production measures may be partially attributed to only feeding the experimental diets for $21 \mathrm{~d}$.

\section{CONCLUSIONS}

Feeding additional MP (although still not adequate based on NRC, 2001) and improving AA balance in the first $21 \mathrm{~d}$ of lactation increased ECM yield by increasing milk fat and protein concentrations, but did not affect DMI. The effects on milk composition continued to be observed over the following 9 wk after cows were switched to a common diet. Potential longer-term benefits of protein supplementation in early lactation should be considered when formulating diets.

Table 9. Effect of phase 1 treatments on milk and milk composition for phase 1 and phase 2 combined $^{1}$

\begin{tabular}{|c|c|c|c|c|c|c|}
\hline \multirow[b]{2}{*}{ Item } & \multicolumn{3}{|c|}{ Treatment $^{2}$} & \multirow[b]{2}{*}{ SEM } & \multicolumn{2}{|c|}{$P$-value ${ }^{3}$} \\
\hline & Control & HMP & MPAA & & MP & AA \\
\hline Milk yield, $\mathrm{kg} / \mathrm{d}$ & 37.3 & 37.7 & 36.9 & 1.34 & $<0.97$ & $<0.62$ \\
\hline $\mathrm{ECM}{ }^{4}{ }^{4} \mathrm{~kg} / \mathrm{d}$ & 37.9 & 38.8 & 38.9 & 1.33 & $<0.55$ & $<0.95$ \\
\hline Lactose, $\%$ & 4.89 & 4.84 & 4.92 & 0.038 & $<0.75$ & $<0.10$ \\
\hline Lactose, $\mathrm{kg} / \mathrm{d}$ & 1.92 & 1.92 & 1.85 & 0.069 & $<0.64$ & $<0.54$ \\
\hline Milk protein, \% & 2.97 & 2.92 & 3.02 & 0.04 & $<0.90$ & $<0.06$ \\
\hline Milk protein, $\mathrm{kg} / \mathrm{d}$ & 1.12 & 1.12 & 1.10 & 0.03 & $<0.78$ & $<0.78$ \\
\hline Milk fat, $\%$ & 3.57 & 3.72 & 4.06 & 0.11 & $<0.02$ & $<0.03$ \\
\hline Milk fat, $\mathrm{kg} / \mathrm{d}$ & 1.36 & 1.43 & 1.49 & 0.06 & $<0.20$ & $<0.49$ \\
\hline
\end{tabular}

${ }^{1}$ No time by treatment interactions. All measures except milk fat percentage were affected by parity $(P<0.05)$. All measures were affected by time $(P<0.05)$ except for milk protein yield.

${ }^{2}$ Diets were control $(16.5 \% \mathrm{CP})$, high metabolizable protein (HMP; $\left.18.5 \% \mathrm{CP}\right)$, and additional MP with a better AA profile (MPAA; $17.5 \% \mathrm{CP}$ ).

${ }^{3} \mathrm{MP}=$ contrast evaluating effect of increased MP (control vs. HMP + MPAA); AA = contrast evaluating effect of altered AA profile with equal MP (HMP vs. MPAA).

${ }^{4} \mathrm{ECM}=0.323 \times \mathrm{kg}$ of milk $+12.82 \times \mathrm{kg}$ of milk fat $+7.13 \times$ milk protein (Tyrrell and Reid, 1965). 


\section{ACKNOWLEDGMENTS}

This study was supported by funds from Perdue Agribusiness Inc. (Salisbury, MD). The authors thank the staff members of the Ohio Agricultural Research and Development Center Krauss Dairy and the Department of Animal Sciences for their excellent and conscientious care of the experimental cows.

\section{REFERENCES}

Agle, M., A. N. Hristov, S. Zaman, C. Schneider, P. Ndegwa, and V. K. Vaddella. 2010. The effects of ruminally degraded protein on rumen fermentation and ammonia losses from manure in dairy cows. J. Dairy Sci. 93:1625-1637.

Appuhamy, J. A., J. R. Knapp, O. Becvar, J. Escobar, and M. D. Hanigan. 2011. Effects of jugular-infused lysine, methionine, and branched-chain amino acids on milk protein synthesis in high-producing dairy cows. J. Dairy Sci. 94:1952-1960.

Appuhamy, J. A., N. A. Knoebel, W. A. D. Nayananjalie, J. Escobar, and M. D. Hanigan. 2012. Isoleucine and leucine independently regulate mTOR signaling and protein synthesis in MAC-T cells and bovine mammary tissue slices. J. Nutr. 142:484-491.

AOAC International. 2000. Official Methods of Analysis of AOAC International. Vol. 1 and 2, 17th ed. AOAC International, Gaithersburg, MD.

Bauman, D. E., and J. M. Griinari. 2001. Regulation and nutritional manipulation of milk fat: Low-fat milk syndrome. Livest. Prod. Sci. 70:15-29.

Blum, J. W., R. M. Bruckmaier, and F. Jans. 1999. Rumen-protected methionine fed to dairy cows: Bioavailability and effects on plasma amino acid pattern and plasma metabolite and insulin concentrations. J. Dairy Sci. 82:1991-1998.

Blum, J. W., F. Jans, W. Moses, D. Frohli, M. Zemp, M. Wanner, I. C. Hart, R. Thun, and U. Keller. 1985. Twenty-four-hour pattern of blood hormone and metabolite concentrations in high-yielding dairy cows: effects of feeding low or high amounts of starch, or crystalline fat. Zentralbl. Veterinarmed. A 32:401-418.

Botts, R. L., R. W. Hemken, and L. S. Bull. 1979. Protein reserves in the lactating dairy cow. J. Dairy Sci. 62:433-440.

Chow, J. M., E. J. Depeters, and R. L. Baldwin. 1990. Effect of rumenprotected methionine and lysine on casein in milk when diets high in fat or concentrate are fed. J. Dairy Sci. 73:1051-1061.

Clark, J. H. 1975. Lactational responses to postruminal administration of proteins and amino acids. J. Dairy Sci. 58:1178-1197.

Cyriac, J., A. G. Rius, M. L. McGilliard, R. E. Pearson, B. J. Bequette, and M. D. Hanigan. 2008. Lactation performance of midlactation dairy cows fed ruminally degradable protein at concentrations lower than National Research Council recommendations. J. Dairy Sci. 91:4704-4713.

Daniel, J. B., N. C. Friggens, P. Chapoutot, H. Van Laar, and D. Sauvant. 2016. Milk yield and milk composition responses to change in predicted net energy and metabolizable protein: A meta-analysis. Animal 10:1975-1985.

Donkin, S. S., G. A. Varga, T. F. Sweeney, and L. D. Muller. 1989. Rumen-protected methionine and lysine-Effects on animal performance, milk protein yield, and physiological measures. J. Dairy Sci. 72:1484-1491.

Duffield, T. F., D. Sandals, K. E. Leslie, K. Lissemore, B. W. McBride, H. Lumsden, P. Dick, and R. Bagg. 1998. Efficacy of monesin for the prevention of subclinical ketosis in lactating dairy cows. J. Dairy Sci. 81:2866-2873.

Edmonson, A. J., I. J. Lean, L. D. Weaver, T. Farver, and G. Webster. 1989. A body condition scoring chart for Holstein dairy cows. J. Dairy Sci. 72:68-78.

Fievez, V., E. Colman, J. M. Castro-Montoya, I. Stefanov, and B. Vlaeminck. 2012. Milk odd- and branched-chain fatty acids as bio- markers of rumen function-An update. Anim. Feed Sci. Technol. 172:51-65.

French, E. A., S. J. Bertics, and L. E. Armentano. 2012. Rumen and milk odd- and branched-chain fatty acid proportions are minimally influenced by ruminal volatile fatty acid infusions. J. Dairy Sci. 95:2015-2026.

Guretzky, N. A., D. B. Carlson, J. E. Garrett, and J. K. Drackley. 2006. Lipid metabolite profiles and milk production for Holstein and Jersey cows fed rumen-protected choline during the periparturient period. J. Dairy Sci. 89:188-200.

Jørgensen, C. H., R. Spörndly, J. Bertilsson, and S. Østergaard. 2016. Invited review: Carryover effects of early lactation feeding on total lactation performance in dairy cows. J. Dairy Sci. 99:3241-3249.

Kim, S. W., J. G. Morris, and Q. R. Rogers. 1995. Dietary soybean protein decreases plasma taurine in cats. J. Nutr. 125:2831-2837.

Komaragiri, M. V., and R. A. Erdman. 1997. Factors affecting body tissue mobilization in early lactation dairy cows. 1. Effect of dietary protein on mobilization of body fat and protein. J. Dairy Sci. 80:929-937.

Law, R. A., F. J. Young, D. C. Patterson, D. J. Kilpatrick, A. R. G. Wylie, and C. S. Mayne. 2009. Effect of dietary protein content on animal production and blood metabolites of dairy cows during lactation. J. Dairy Sci. 92:1001-1012.

Lee, C., F. Giallongo, A. N. Hristov, H. Lapierre, T. W. Cassidy, K. S. Heyler, G. A. Varga, and C. Parys. 2015. Effect of dietary protein level and rumen-protected amino acid supplementation on amino acid utilization for milk protein in lactating dairy cows. J. Dairy Sci. 98:1885-1902.

Lee, C., A. N. Hristov, T. W. Cassidy, K. S. Heyler, H. Lapierre, G. A. Varga, M. J. de Veth, R. A. Patton, and C. Parys. 2012a. Rumenprotected lysine, methionine, and histidine increase milk protein yield in dairy cows fed a metabolizable protein-deficient diet. J. Dairy Sci. 95:6042-6056.

Lee, C., A. N. Hristov, K. S. Heyler, T. W. Cassidy, H. Lapierre, G. A. Varga, and C. Parys. 2012b. Effects of metabolizable protein supply and amino acid supplementation on nitrogen utilization, milk production, and ammonia emissions from manure in dairy cows. J. Dairy Sci. 95:5253-5268.

Leonardi, C., M. Stevenson, and L. E. Armentano. 2003. Effect of two levels of crude protein and methionine supplementation on performance of dairy cows. J. Dairy Sci. 86:4033-4042.

NRC. 2001. Nutrient Requirements of Dairy Cattle. 7th rev. ed. Natl. Acad. Press, Washington DC.

Noftsger, S., N. R. St-Pierre, and J. T. Sylvester. 2005. Determination of rumen degradability and ruminal effects of three sources of methionine in lactating cows. J. Dairy Sci. 88:223-237.

Overton, T. R., D. W. LaCount, T. M. Cicela, and J. H. Clark. 1996. Evaluation of a ruminally protected methionine product for lactating dairy cows. J. Dairy Sci. 79:631-638.

Palmquist, D. L., and T. C. Jenkins. 2003. Challenges with fats and fatty acid methods. J. Anim. Sci. 81:3250-3254.

Papas, A. M., J. L. Vicini, J. H. Clark, and S. Peirce-Sandner. 1984. Effect of rumen-protected methionine on plasma free amino acids and production by dairy cows. J. Nutr. 114:2221-2227.

Schwab, C. G., N. L. Whitehouse, D. Luchini, and B. Sloan. 2009. Reevaluation of the breakpoint estimates for the NRC (2001) required concentrations of lysine and methionine in metabolizable protein for maximal content and yield of milk protein. J. Dairy Sci. 92(suppl. 1):103. (abstr.).

Socha, M. T., D. E. Putnam, B. D. Garthwaite, N. L. Whitehouse, N. A. Kierstead, C. G. Schwab, G. A. Ducharme, and J. C. Robert. 2005. Improving intestinal amino acid supply of pre- and postpartum dairy cows with rumen-protected methionine and lysine. J. Dairy Sci. 88:1113-1126.

Tyrrell, H. F., and J. T. Reid. 1965. Prediciton of the energy value of cow's milk. J. Dairy Sci. 48:1215-1223.

Valadares, R. F. D., G. A. Broderick, S. C. Valadares, and M. K. Clayton. 1999. Effect of replacing alfalfa silage with high moisture corn on ruminal protein synthesis estimated from excretion of total purine derivatives. J. Dairy Sci. 82:2686-2696. 
Vlaeminck, B., V. Fievez, S. Tamminga, R. J. Dewhurst, A. van Vuuren, D. De Brabander, and D. Demeyer. 2006. Milk odd- and branched-chain fatty acids in relation to the rumen fermentation pattern. J. Dairy Sci. 89:3954-3964.

Wang, C., H. Y. Liu, Y. M. Wang, Z. Q. Yang, J. X. Liu, Y. M. Wu, T. Yan, and H. W. Ye. 2010. Effects of dietary supplementation of methionine and lysine on milk production and nitrogen utilization in dairy cows. J. Dairy Sci. 93:3661-3670.

Weekes, T. L., P. H. Luimes, and J. P. Cant. 2006. Responses to amino acid imbalances and deficiencies in lactating dairy cows. J. Dairy Sci. 89:2177-2187.

Weiss, W. P., L. B. Willett, N. R. St-Pierre, D. C. Borger, T. R. McKelvey, and D. J. Wyatt. 2009. Varying forage type, metabolizable protein concentration, and carbohydrate source affects manure excretion, manure ammonia, and nitrogen metabolism of dairy cows. J. Dairy Sci. 92:5607-5619.
Weiss, W. P., and D. J. Wyatt. 2000. Effect of oil content and kernel processing of corn silage on digestibility and milk production by dairy cows. J. Dairy Sci. 83:351-358.

Weiss, W. P., and D. J. Wyatt. 2003. Effect of dietary fat and vitamin E on alpha-tocopherol in milk from dairy cows. J. Dairy Sci. 86:3582-3591.

Xu, S., J. H. Harrison, W. Chalupa, C. Sniffen, W. Julien, H. Sato, T. Fujieda, K. Watanabe, T. Ueda, and H. Suzuki. 1998. The effect of ruminal bypass lysine and methionine on milk yield and composition of lactating cows. J. Dairy Sci. 81:1062-1077.

Zanton, G. I., G. R. Bowman, M. Vázquez-Añón, and L. M. Rode. 2014. Meta-analysis of lactation performance in dairy cows receiving supplemental dietary methionine sources or postruminal infusion of methionine. J. Dairy Sci. 97:7085-7101. 